\title{
INTRODUCTION OF ROOT TRAINERS TO FOREST NURSERIES IN SRI LANKA
}

\author{
D Tilakaratna \\ Research Officer, Forest Research Centre \\ Kumbalpola, Boyagane
}

Use of poly bags for the production of tree seedlings result in several disadvantages due to distortion of the root system. Poor lateral root formation, root spiralling and bending of tap root occurs in poly bags and affects the growth of the tree. Slow growth, poor draught tolerance and lack of wind firmness are some of the major problems resulting from the use of poly bags.

A new container called root trainer has been developed to overcome these problems.

Root trainers were introduced to the forest research centre nursery at Kumbalpola with a view to gain first hand experience on the handling maintenance and preparation of potting media. The results have been encouraging. A good potting media suitable for the use in root trainers was developed. Better root growth was observed in root trainer grown seedlings. Maintenance, handling and field planting were much easier compare to poly bag grown seedlings. It is concluded that the root trainers can be successfully used for the production of tree seedlings.

Proceedings of the Third Annual Forestry Symposium 1997, of the Department of Forestry and Environmental Science, University of Sri Jayewardenepura, Sri Lanka 